\title{
Questioning the Standard of Proof
}

\author{
The Purpose of the ICC Confirmation of Charges \\ Procedure
}

\author{
Triestino Mariniello*
}

\begin{abstract}
The article begins with a discussion of the judicial debate on the confirmation procedure before the International Criminal Court, which arose in the pretrial proceedings in the Gbagbo case. The author argues that in finding that a confirmation of the charges decision should be based on 'the strongest possible case based on a largely completed investigation', Pre-Trial Chamber I imposed too high a standard of proof, and that adopting such standards could potentially disrupt proceedings by blurring the boundaries between pretrial and trial stages. This would ultimately be detrimental to the rights of the accused, both in terms of the right to a speedy trial and the presumption of innocence. Even if available evidence does not appear sufficient to sustain a possible conviction at trial, a case could still be worthy of trial if the PreTrial Chamber established that doubts and inconsistencies regarding the credibility of the evidence would be more properly addressed and solved through the examination of witnesses.
\end{abstract}

\section{Introduction}

On 3 June 2013, Pre-Trial Chamber I of the International Criminal Court (ICC) found that the evidence presented by the Prosecutor did not meet the required threshold for confirming the charges and decided to adjourn the confirmation

* Senior Lecturer in Law, Edge Hill University (UK). This article elaborates upon thoughts that I have published earlier with Mr Niccolò Pons. For further details on the previous work, see T. Mariniello and N. Pons, 'The Confirmation of Charges at the International Criminal Court: A Tale of Two Models', in T. Mariniello (ed.), The International Criminal Court in Search of its Purpose and Identity (Routledge, 2015) 217-241. I wish to express my gratitude to Dr Peter Langford and Dr Sergey Vasiliev for their comments on an earlier draft. All errors and omissions remain mine alone. [Mariniet@edgehill.ac.uk] 
hearing in the Gbagbo case pursuant to Article 61(7)(c) of the ICC Statute (Adjournment Decision). ${ }^{1}$ The majority of the Pre-Trial Chamber requested for the first time since the establishment of the ICC - that for the purposes of the confirmation of charges, the Prosecutor must present her strongest possible case based on a largely completed investigation. Judge Fernández de Gurmendi (now ICC President) dissented from the majority, by stressing that the ICC Statute does not establish any obligation for the Prosecutor to submit to the Chamber all her evidence or to present to the Chamber 'her strongest possible case. ${ }^{2}$ On 12 June 2014, a different majority committed Laurent Gbagbo for trial (Confirmation Decision). ${ }^{3}$ Pre-Trial Chamber I departed from the approach taken in the Adjournment Decision, by setting aside the 'largely completed investigation' requirement. The majority insisted on the limited scope and purpose of the confirmation of charges, and asserted that the confirmation decision does not have to address every submission by the parties, but merely those necessary for the Chamber's determination under Article 61(7) of the Statute. ${ }^{4}$ In her Dissenting Opinion, Judge Van den Wyngaert disagreed on the interpretation of the evidentiary threshold required to send an individual for trial. ${ }^{5}$ She held that this standard of proof is met only if the evidence has a realistic chance of supporting a conviction beyond reasonable doubt.' 6

Article 61(7) of the ICC Statute provides that the Pre-Trial Chamber shall, on the basis of the hearing, determine whether there is sufficient evidence to establish substantial grounds to believe that the person committed each of the crimes charged' (emphasis added). The pretrial proceedings in the Gbagbo case are characterized by an unprecedented judicial dispute concerning the standard of proof under Article 61(7), as well as the object and purpose of the confirmation procedure.

The Adjournment Decision adopted a strikingly strict approach to the application of the standard of proof to the evidence presented by the Prosecutor at the confirmation hearing. The Prosecutor's supposed obligation to have a largely completed investigation amounts to an attempt by the bench to supervise the conduct of the investigation by the Prosecutor, to prevent the repetition of scenarios already experienced in other cases at the trial stage. This decision represents a radical departure from the predominant view of the object and purpose of the confirmation of charges. Indeed, the legal requirement providing that the Pre-Trial Chamber decides on the basis of a largely completed

1 Decision adjourning the hearing on the confirmation of charges pursuant to article 61(7)(c)(i) of the Rome Statute, Gbagbo (ICC-02/11-01/11-432), Pre-Trial Chamber I, 3 June 2013 ('Gbagbo Adjournment Decision').

2 Dissenting Opinion of Judge Fernández de Gurmendi, Gbagbo Adjournment Decision, 6 June 2013, § 14 ('Dissenting Opinion of Judge Fernández').

3 Decision on the Confirmation of Charges against Laurent Gbagbo, Gbagbo (ICC-02/11-01/ 11-656-Red), Pre-Trial Chamber I, 12 June 2014 ('Gbagbo Confirmation Decision').

4 Ibid., \$\$21-23.

5 Gbagbo Confirmation Decision, Dissenting Opinion of Judge Van den Wyngaert, supra note 3.

6 Ibid., $\$ 4$. 
investigation and, thus, on a trial-ready evidence, reveals a view of the purpose of the confirmation of charges, which is seemingly oriented to a preliminary assessment of guilt or innocence of the suspect.

In contrast to the Adjournment Decision, the Confirmation Decision did not request the Prosecutor to submit 'all her evidence', and evaluated the evidence only in terms of its probative value, without assessing the manner in which the Prosecutor led the investigation. In the Confirmation Decision, the standard of proof for sending a case to trial was interpreted by the Pre-Trial Chamber I in light of the limited purpose of the confirmation of charges hearing as opposed to trial proceedings. This interpretation of the evidentiary threshold, under Article 61(7), takes into account the restricted role of the Pre-Trial Chambers as rapid and efficient gatekeepers, confined to identifying and separating cases that should go to trial and those that should not advance to the trial stage. ${ }^{7}$

Therefore, the underlying aim of this article is twofold. First, it aims to critically assess the judicial debate on the confirmation procedure, which arose in the Gbagbo pretrial proceedings. Secondly, following this critical examination, the article engages in a further reflection on the object and purpose of the confirmation of charges procedure. It considers that the role of pretrial judges does not encompass a prognosis for the likelihood of the suspect's guilt, and explains how their role is confined to supervising the legitimacy of the Prosecutor's request to commit an individual for trial, by assessing the utility of a full trial to resolve the contradictions of written evidence.

Section 2 provides a brief description of the structure and functions of the confirmation of charges in the Statute. Section 3 examines the standard of proof of substantial grounds to believe, with a particular focus on the differences between the evidentiary test under Article 61(7) and the test for the confirmation of indictment before the ad hoc tribunals. Section 4 critically assesses conflicting judicial interpretations of the confirmation procedure, which arose in the entirety of the Gbagbo pretrial proceedings. To this end, Section 4 systematically addresses the different approaches of the ICC to the standard of proof. Thus, Section 5 concentrates upon whether, and to what extent, the 'largely complete investigation' requirement is consistent with the Statute. It provides a critical analysis of this requirement in light of both the limited scope and purpose of the confirmation of charges, and the discretion of the Prosecutor to choose the type and quantity of evidence she may rely on to meet the 'substantial grounds to believe' threshold. Section 6 explains how the legal requirement that the Pre-Trial Chamber decides on the basis of a largely completed investigation distorts the object and purpose of the confirmation of charges procedure, which is, thus, questionably transformed into a preliminary assessment of the individual's guilt. This would result in a challenge to the exclusive competences of Trial Chambers and the expeditiousness

7 For a detailed analysis of the ICC jurisprudence on the limited scope of the confirmation of charges and the role of Pre-Trial Chambers as mere 'gatekeepers', see S. Vasiliev, 'International Criminal Trials: A Normative Theory' (Ph.D. Thesis, University of Amsterdam), Vol. I, at 398-405. 
of the proceedings, as well as prejudice to the rights of the accused. Therefore, the article argues that, even if the available evidence does not appear sufficient to sustain a possible conviction at trial, a case could still be worthy of trial if the Pre-Trial Chamber established that doubts and inconsistencies regarding the credibility of the evidence would be more properly addressed and solved through the examination of witnesses at trial.

The pretrial proceedings in the Gbagbo case indicate that the ICC is still in a situation of institutional uncertainty regarding the status and nature of the confirmation of charges. ${ }^{8}$ It is such hesitation, and its accompanying difficulties, that, in turn, require a continuous and sustained reflection and dialogue among scholars and legal practitioners in the field of international criminal justice.

\section{The Structure and Function of the Confirmation of Charges Procedure}

The confirmation of charges is the stage at which a Pre-Trial Chamber makes a determination whether the case is to be sent for trial. The Prosecutor and the Defence are the parties to the confirmation procedure and, as such, they may submit their evidence and call witnesses. ${ }^{9}$ Pursuant to Article 61(6) of the Statute, the suspect may also object to the charges, challenge the evidence presented by the Prosecutor and present evidence. In addition, victims who have suffered personal harm linked to the charges against the accused may participate in the confirmation proceedings through their legal representatives. ${ }^{10}$

The confirmation of charges constitutes one of the main innovations introduced by the drafters of the Statute in the field of international criminal justice. Statutes of other international or internationalized criminal tribunals do not contain such a procedure. Indeed, the confirmation of charges is structurally different from the confirmation of indictment before the International Criminal Tribunal for the former Yugoslavia and for Rwanda (ICTY and ICTR). Whereas the latter is a procedure, conducted ex parte by one judge in the absence of the Defence, ${ }^{11}$ the former is deliberately envisaged as an adversarial hearing, whereby the person charged has the right to be present and contest the evidence before a Pre-Trial Chamber composed of three Judges. Thus, ICC Pre-Trial Chambers are vested with the authority to assess the evidence, including the power to determine its relevance, admissibility and weight. For instance, Rule 63(2) of the Rules and Procedures of Evidence establishes that any Chamber, including the Pre-Trial Chamber, shall have the authority, in accordance with the discretion described in Article 64, paragraph 9, to assess freely all evidence submitted in order to determine its relevance or

8 C. Safferling, International Criminal Procedure (Oxford University Press, 2012), at 337.

9 Art. 61(5) and 61(6)(c) ICCSt.

10 Art. 68(3) ICCSt.

11 See Art. 19 ICTYSt and Art. 18 of the ICTRSt. See also Rule 47(b) of the ICTY and ICTR RPE. 
admissibility in accordance with Article 69 ... . In addition, Article 69(4) of the Statute, which shall apply mutatis mutandis at the confirmation hearing, ${ }^{12}$ provides that ' $[\mathrm{t}]$ he Court may rule on the relevance or admissibility of any evidence, taking into account, inter alia, the probative value of the evidence and any prejudice that such evidence may cause to a fair trial or to a fair evaluation of the testimony of a witness, in accordance with the Rules of Procedure and Evidence'

As clarified by a consolidated ICC jurisprudence, the confirmation hearing is neither a trial before the trial nor a mini-trial. ${ }^{13}$ Thus, judges sitting in PreTrial Chambers are not required to decide on whether or not the person is criminally responsible beyond reasonable doubt for the crimes allegedly committed. ${ }^{14}$ In other words, Pre-Trial Chambers do not have the authority to enter into an initial, detailed analysis of the guilt of the person or to evaluate whether the evidence is sufficient to sustain a future conviction. ${ }^{15}$ The established jurisprudence of the Court has insisted on the importance of the role of Pre-Trial Chambers in ensuring judicial economy when determining which cases merit being heard at trial. This function has been framed in the context of the limited purpose of the confirmation of charges hearing as opposed to trial proceedings. This is reflected in the different evidentiary thresholds applicable to these two stages. By referring to the report of the United Nations High Commission for Human Rights, in the Lubanga case, Pre-Trial Chamber I found that the confirmation of charges is limited to committing for trial only those suspects against whom sufficiently compelling charges, going beyond mere theory or suspicion, have been brought. ${ }^{16}$ Pre-Trial Chambers have frequently emphasized that the confirmation hearing aims to protect the suspect 'against wrongful prosecution and ensuring judicial economy by allowing to distinguish between cases that should go to trial from those that should not: ${ }^{17}$ In this regard, it can be argued that the main purpose of the confirmation decision is to protect the charged person against wrongful and wholly unfounded charges by placing the Prosecutor's work under early assessment.

12 See Judgment on the appeal of the Prosecutor against the decision of Pre-Trial Chamber I of 16 December 2011 entitled Decision on the confirmation of charges, Mbarushimana (ICC-01/ 04-01/10-514), Appeals Chamber, 30 May 2012 ('Mbarushimana Appeal Judgment'), §41.

13 See, inter alia, Decision on the admissibility for the confirmation hearing of the transcripts of interview of deceased Witness 12, Katanga (ICC-01/04-01/07-412), Pre-Trial Chamber I, 18 April 2008, $\$ 64$.

14 For a detailed assessment of the evidentiary threshold of reasonable doubt in international criminal justice, see C.M. Roha, 'Reasonable Doubt Standard of Proof in International Criminal Trials', in K.A.A. Kahn, C. Buisman and C. Gosnell (eds), Principles of Evidence in International Criminal Justice (Oxford University Press, 2010) 650-670.

15 Decision on the Confirmation of Charges, Abu Garda (ICC-02/05-02/09-243-Red), Pre-Trial Chamber I, 8 February 2010 ('Garda Confirmation Decision'), § 40.

16 Decision on the Confirmation of Charges, Lubanga (ICC-01/04-01/06-803-tEN), Pre-Trial Chamber I, 14 May 2007 ('Lubanga Confirmation Decision'), §37.

17 Decision Pursuant to Article 61(7)(a) and (b) of the Rome Statute on the Charges of the Prosecutor Against Jean-Pierre Bemba Gombo, Bemba (ICC-01/05-01/08-424), Pre-Trial Chamber II, 15 June 2009 ('Bemba Confirmation Decision'), § 28. See also O. Bekou, 'Prosecutor v Thomas Lubanga Dyilo', 8 Human Rights Law Review (2008) 343-355, at 344. 
To achieve this objective, the confirmation hearing has to ensure that "no case proceeds to trial without sufficient evidence to establish substantial grounds to believe that the person committed the crime or crimes with which he has been charged. ${ }^{18}$

Following the assessment of the evidence disclosed between the parties and communicated to the Chamber, judges may (i) confirm the charges; ${ }^{19}$ (ii) decline to confirm the charges, ${ }^{20}$ or (iii) adjourn the hearing and request the Prosecutor to consider (a) providing further evidence or conducting further investigation with respect to a particular charge; ${ }^{21}$ or (b) amending a charge because the evidence submitted appears to establish a different crime within the jurisdiction of the Court. ${ }^{22}$

\section{Sending a Case to Trial: 'Substantial Grounds to Believe' as the Evidentiary Threshold}

Despite the importance of the confirmation of charges within the ICC proceedings, the Statute does not clarify the concept of 'substantial grounds to believe' under Article 61(7). To define the evidentiary threshold in question, judges have relied on human rights jurisprudence of the European Court of Human Rights and found that this test requires 'strong grounds for believing' or that 'substantial grounds for believing' are shown. ${ }^{23}$ The Pre-Trial Chamber, in the Bemba case, provided a literal interpretation of the term 'substantial' as 'significant' or 'solid.. ${ }^{24}$ Therefore, for the Prosecutor to meet the evidentiary burden, under Article 61(7), she 'must offer concrete and tangible proof demonstrating a clear line of reasoning underpinning its specific allegations. ${ }^{25}$

The ICC Prosecutor proposed an interpretation of the evidentiary test under Article 61(7), based on the ICTY and ICTR prima facie standard, referring to similarities between confirmation of charges before the ICC and confirmation of indictment before the ad hoc tribunals. ${ }^{26}$ It is important to note that Rule 47 (a) of the Rules of Procedure and Evidence ('Rules') of the ad hoc tribunals establishes that the Prosecutor may submit an indictment if he or she is satisfied that there is sufficient evidence providing 'reasonable grounds for

18 Decision on the Confirmation of Charges, Katanga and Ngudjolo (ICC-01/04-01/07-717), Pre-Trial Chamber I, 30 September 2008 ('Katanga and Ngudjolo Confirmation Decision'), §63.

19 Art. (61)(7)(a) ICCSt.

20 Art. (61)(7)(b) ICCSt.

21 Art. $(61)(7)(c)(i)$ ICCSt.

22 Art. 61(7)(c)(ii) ICCSt.

23 Lubanga Confirmation Decision, supra note 16, § 38; Katanga and Ngudjolo Confirmation Decision, supra note $18, \S 65$.

24 Bemba Confirmation Decision, supra note 17, § 29.

25 See Lubanga Confirmation Decision, supra note 16 , $\$$ 38-39. This reasoning was upheld by the same Chamber in Katanga and Ngudjolo Confirmation Decision, supra note 18, $\$ 65$.

26 See Prosecution's Document Addressing Matters that were Discussed at the Confirmation Hearing, Lubanga (ICC-01/04-01/06-749), Pre-Trial Chamber I, 4 December 2006, § 11. 
believing' that a person has committed a crime falling within the jurisdiction of the tribunals. ${ }^{27}$ The same standard applies when establishing the existence of a prima facie case to confirm an indictment under Articles 19(1) and 18(1) of the Statutes of the ICTY and the ICTR, respectively. ${ }^{28}$

The ICC Prosecutor's interpretation equating the Article 61 standard for the confirmation of charges with the prima facie standard at the ad hoc tribunals is not persuasive. It is true that, while the ICC is not bound by the jurisprudence of the ICTY and ICTR, judges of the ICC have frequently referred to the practice of the ad hoc tribunals, especially in the area of substantive criminal law. However, the structural differences between the confirmation of indictment before the ICTY and ICTR, on the one hand, and the confirmation of charges before the ICC, on the other, militate against taking the ad hoc Statutes and Rules into account to interpret procedural rules under Article 61 of the ICC Statute. Indeed, whereas the former is a procedure conducted by one judge ex parte in the absence of the Defence, ${ }^{29}$ the latter is purposely envisaged as an adversarial hearing, whereby the person charged has the right to be present and contest the evidence before a Pre-Trial Chamber composed of three judges. ${ }^{30}$

These differences have been stressed by the Appeals Chamber in the Mbarushimana case, where the judges found inappropriate the Prosecutor's analogy between the confirmation of charges hearing before the ICC and the ICTY and ICTR procedures. ${ }^{31}$ Judges sitting in the Appeals Chamber refused to accept that the ICC was bound by the procedural rules of the ad hoc tribunals, which allow for determination of whether cases can proceed without the evaluation of the credibility of evidence, ${ }^{32}$ whereas at the stage of the confirmation of charges the Pre-Trial Chambers may assess the contested evidence and resolve ambiguities, contradictions, inconsistencies or doubts as to credibility introduced by the contestation of the evidence. ${ }^{33}$

In addition, the ad hoc tribunals operate with different evidentiary standards with respect to the confirmation of indictment. Indeed, the confirmation of charges at the ICC is associated with a higher evidentiary threshold of 'substantial grounds to believe' in place of the lower standard of 'reasonable grounds' for the purpose of confirming the indictment before the ICTY and ICTR. This test for the confirmation of indictment before the ICTY and ICTR presents similarities with the 'reasonable grounds to believe' standard within the meaning of Article 58(1)(a) of the ICC Statute regarding arrest, rather

27 Rule 47(b) ICTY and ICTR RPE.

28 See G. de Beco, 'The Confirmation of Charges before the International Criminal Court: Evaluation and First Application', 7 International Criminal Law Review (2007) 469-481.

29 Art. 19 ICTYSt.; Art. 18 ICTRSt. See also Rule 47(b) ICTY and ICTR RPE.

30 Art. 61(6) ICCSt. See also A.J. Burrow, 'The Standard of Proof in Pre-Trial Proceedings', in Khan, Buisman and Gosnell (eds), supra note 14, 671-692, at 674-676.

31 Mbarushimana Appeal Judgment, supra note 12, §43.

32 Ibid.

33 Ibid., §40. 
than with the standard at the confirmation of charges stage. ${ }^{34}$ The provision concerning the issuance of an arrest warrant before the ICC requires a lower standard than the confirmation of charges. ${ }^{35}$

Thus, the standard under Article 61(7) falls between the threshold of 'reasonable grounds to believe', required for the issuance of a warrant of arrest, and 'beyond a reasonable doubt', required by Article 66(3) for the conviction. ${ }^{36}$ The evidence submitted to the Pre-Trial Chamber under Article 61 must be analysed and assessed as a whole. ${ }^{37}$ Judges sitting in Pre-Trial Chambers do not have the mandate to convince the Trial Chamber that the accused is guilty 'beyond a reasonable doubt' as required by Article 66(3). Nor may they anticipate whether the Trial Chamber will enter a conviction or an acquittal on all or part of the charges. Instead, the mandate of the Pre-Trial Chamber judges is to assess, at the moment they hear the case, whether there is sufficient evidence to establish substantial grounds to believe that the suspect committed each of the crimes charged and, accordingly, whether it is justified to commit him for trial for the Trial Chamber to hear the entirety of the evidence available, including (eventually) the live testimony of all witnesses. In concrete terms, however, the decision to confirm the charges and commit a suspect for trial has a number of implications that, technically, the PTC judges should not take into consideration in their legal assessment of the evidence but that may, nonetheless, play an indirect and decisive role in their evaluation. These are, for example, the possibility that the accused will be kept in detention for several years while awaiting a judgment (should the grounds for detention remain), the need to put in place a series of protective measures for the witnesses and to call them for testimony, the likely participation of a considerable number of victims in the proceedings given the widespread nature of the crimes usually charged before the ICC, and, last but not least, the judicial and financial resources normally required to undertake an international criminal trial.

\section{4. 'Sufficient Evidence' for the Confirmation of Charges: Diverging Approaches in the Gbagbo Proceedings}

\section{A. The Adjournment Decision}

In Gbagbo, the majority of Pre-Trial Chamber I, Presiding Judge Fernández de Gurmendi dissenting, decided to adjourn the confirmation hearing pursuant to Article 61(7)(c)(i) of the Statute, and request the Prosecutor to consider the

34 Ibid., $\$ 43$.

35 Ibid.

36 Decision on the Confirmation of Charges Pursuant to Article 61(7)(a) and (b) of the Rome Statute, Ruto, Kosgey and Sang (ICC-01/09-01/11-373), Pre-Trial Chamber II, 23 January 2012 ('Ruto, Kosgey and Sang Confirmation Decision'), $\$ 40$.

37 Lubanga Confirmation Decision, supra note $16, \S 38$. 
possibility of conducting a more in-depth investigation or providing additional evidence with respect to specific issues. ${ }^{38}$ Laurent Gbagbo, former president of Ivory Coast, had been charged by the Prosecutor with four counts of crimes against humanity - murder, rape and other forms of sexual violence, persecution and 'other inhumane acts', allegedly committed during the post-election violence in Ivory Coast, between 16 December 2010 and 12 April 2011. ${ }^{39}$ The majority stated that the evidence presented by the Prosecutor, viewed as a whole, 'although apparently insufficient, does not appear to be so lacking in relevance and probative value that it leaves the Chamber with no choice but to decline to confirm the charges under article 61(7)(b) of the Statute. ${ }^{40}$

In particular, the Chamber held that the majority of the incidents used by the Prosecutor to support her allegations for the existence of an 'attack directed against any civilian population, as required by the definition of crimes against humanity, 'are proven solely with anonymous hearsay from NGO Reports, United Nations reports and press articles. ${ }^{41}$ The Chamber stressed that it was unable to attach much probative value to this type of material submitted by the Prosecutor, ${ }^{42}$ and, interestingly, pointed out that past jurisprudence of Pre-Trial Chambers may have been forgiving in this respect, thus leading the Prosecutor not to present all her evidence or largely complete her investigation .... ${ }^{43}$ According to the majority, 'many of these incidents are described in very summary fashion, making it difficult for the Chamber to determine whether the perpetrators acted pursuant to or in furtherance of a policy to attack a civilian population as required by article $7(2)(a)$ of the Statute. ${ }^{44}$

Judge Fernández de Gurmendi argued in dissent that the expectation that the Prosecutor must present all her evidence at the confirmation of charges hearing or her strongest case based on a largely completed investigation, resembles more a desirable policy or best practice, rather than an obligation stemming from the ICC's applicable law. ${ }^{45}$ In this regard, she found that, even if the Prosecutor has completed an investigation, there is no legal requirement for her to submit to the Chamber all her evidence or to present to the Chamber 'her strongest possible case. ${ }^{46}$ According to the dissenting Judge, the Preparatory Works to the Statute also seem to suggest that providing the Pre-Trial Chamber and, by implication, the Defence with the entire case file of the Prosecutor was not considered to be an optimal solution, as it would have

38 Gbagbo Adjournment Decision, supra note 1.

39 Amended Document Confirming the Charges, Gbagbo (ICC-02/11-01/11-592-Conf-Anx3-Corr.),

Office of the Prosecutor, 13 January 2014.

40 Gbagbo Adjournment Decision, supra note $1, \S 15$.

41 Ibid., $\S 36$

42 Ibid., $\S 35$.

43 Ibid., $\$ 37$.

44 Ibid., $\$ 36$.

45 Dissenting Opinion of Judge Fernández, supra note 2, § 15.

46 Ibid., $§ 17$. 
entailed unnecessary delays in the smooth conduct of the pretrial proceedings "if the evidence collected in the case was excessive. ${ }^{47}$

The approach taken by the majority significantly departs from the consolidated interpretation of the standard of proof under Article 61(7) in the ICC's jurisprudence. Even if Pre-Trial Chamber I left the interpretation of the evidentiary threshold of 'substantial grounds to believe' virtually untouched, ${ }^{48}$ it inferred from this provision the Prosecutor's alleged obligation at the confirmation hearing to present the strongest possible case based on a largely completed investigation. In the Lubanga case, Pre-Trial Chamber I had already tried to establish that the investigation must be completed prior to the confirmation hearing. ${ }^{49}$ However, this decision was immediately reversed by the Appeals Chamber, excluding any legal requirements that investigation must be concluded by the time the confirmation hearing starts. ${ }^{50}$

In the Adjournment Decision, Pre-Trial Chamber I arguably vested itself with the power to revise the manner in which the Prosecutor conducted the investigation in that case. The Pre-Trial Chamber also listed the precise issues in respect of which the further investigatory steps should have been taken by the Prosecutor. ${ }^{51}$ Indeed, while Article 61(7)(c)(i) establishes that the Pre-Trial Chamber may adjourn the hearing and request the Prosecutor to consider "providing further evidence or conducting further investigation with respect to a particular charge' (emphasis added), the majority also provided specific instruction to the Prosecutor to undertake certain investigative activities as opposed to others, according to the issues that, in the view of the Judges, had to be investigated further and substantiated with evidence. ${ }^{52}$

With regard to the evidence presented by the Prosecutor, while acknowledging that Article 61(5) of the Statute only requires the Prosecutor to support each charge with 'sufficient' evidence, the majority stated that, 'the Chamber must assume that the Prosecutor has presented her strongest possible case based on a largely completed investigation., ${ }^{53}$ In the view of the majority, this assumption reflects the need to ensure continuity in the presentation of the case and safeguard the rights of the Defence, "which should not be presented

47 Ibid., $\$ 20$.

48 Gbagbo Adjournment Decision, supra note 1, §§ 16-18.

49 Decision Establishing General Principles Governing Applications to Restrict Disclosure pursuant to Rule 81 (2) and (4) of the Rules of Procedure and Evidence, Lubanga (ICC-01/04-01/ 06-108-Corr), Pre-Trial Chamber I, 19 May 2006.

50 Judgment on the Prosecutor's appeal against the decision of Pre-Trial Chamber I entitled 'Decision Establishing General Principles Governing Applications to Restrict Disclosure pursuant to Rule 81(2) and (4) of the Rules of Procedure and Evidence', Lubanga (ICC-01/04-01/ 06-568), Appeals Chamber, 13 October 2006, §54.

51 Dissenting Opinion of Judge Fernández, supra note 2, §44.

52 Ibid., $\$ 44(6)$. As a matter of example, in respect one of the incidents charges by the Prosecutor, the Majority of Pre-Trial Chamber I requested 'any forensic evidence indicating who fired the ammunitions and what their alleged target was'.

53 Gbagbo Adjournment Decision, supra note 1, § 25. 
with a wholly different case at trial. ${ }^{54}$ In addition, it ensures a rapid commencement of the trial, should the charges be confirmed, consistent with the right of the accused to be tried without undue delay, as enshrined in Article $67(1)(c)$ of the Statute. ${ }^{55}$

\section{B. The Confirmation Decision}

One year after the Adjournment Decision, a different majority, comprising Judges Kaul and Fernández de Gurmendi, confirmed the charges against Gbagbo. ${ }^{56}$ Pre-Trial Chamber I committed the suspect for trial, by concluding that there are substantial grounds to believe he is responsible of crimes against humanity. In reaching this conclusion, interestingly, the Pre-Trial Chamber set aside the largely completed investigation requirement and, in several circumstances, stressed the limited scope and purpose of the confirmation of charges. ${ }^{57}$ In light of such a limited scope and objective, the Chamber emphasized how its decision 'does not explicitly address each and every submission and participants, but only those that are necessary to provide sufficient reasoning for the Chamber's determination under Article 61(7) of the Statute. ${ }^{58}$ The Pre-Trial Chamber asserted its authority to evaluate the evidence, but it reiterated its reduced role in reaching conclusions on the credibility of witnesses. ${ }^{59}$ This means that once the 'substantial grounds to believe' threshold is established, challenges to the credibility of evidence are to be more thoroughly addressed at trial. ${ }^{60}$

In her Dissenting Opinion, Judge Van den Wyngaert rejected that the evidence submitted was sufficiently strong to commit the suspect to trial. ${ }^{61}$ Indeed, she held that the evidentiary threshold is met only if "the evidence has a realistic chance of supporting a conviction beyond reasonable doubt, ${ }^{62}$ and that "there must be at least enough of an evidentiary basis to sustain a possible conviction on the assumption that these questions are resolved in favour of the Prosecutor at trial.63

The Confirmation Decision and the attached Dissenting Opinion reveal different evaluations of the probative value of the incriminating evidence among Judges sitting in Pre-Trial Chamber I. Most importantly, they confirm the existence of judicial divergences related to the interpretation of the standard of proof under Article 61(7) of the Statute. As will be discussed in the following

54 Ibid., § 25. See also Decision on defence application pursuant to Article 64(4) and related requests, Kenyatta (ICC-01/09-02/11-728), Trial Chamber V, 26 April 2013, §§ 118-123.

55 Gbagbo Adjournment Decision, supra note 1, § 25.

56 Gbagbo Confirmation Decision, supra note 3.

57 Ibid., §§ 21-23.

58 Ibid., § 23.

59 Ibid., § 21.

60 Ibid.

61 Dissenting Opinion of Judge Van den Wyngaert, supra note 5.

62 Ibid., $\$ 4$.

63 Ibid. 
sections, these conflicting views relating to the concept of 'sufficient evidence' for the purposes of committing an individual to trial derive from different interpretations of the object and purpose of the confirmation of charges procedure. ${ }^{64}$

In the Confirmation Decision, the majority moved forward by looking back, rejecting the need for the Prosecutor to present the strongest possible case based on a largely completed investigation for the confirmation of charges. Indeed, this Decision reflects the established approach followed by various Pre-Trial Chambers, which have simply confined themselves to evaluating the strength of the case in light of Article 61(5) standard based on the evidence submitted, without examining whether the case had been sufficiently investigated by the Prosecutor. The conduct of the investigation by the Prosecutor prior to the confirmation of charges had been the object of inquiry for some Pre-Trial Chambers. Judges had addressed the question whether the screening role of Pre-Trial Chambers encompasses the power to assess the manner in which the Prosecutor has conducted the investigation. They had concluded that they may evaluate the result of the Prosecutor's investigation, that is, the evidence, but not the conduct of the investigation itself. As underlined by PreTrial Chamber II, "the scope of determination under article 61(7) of the Statute relates to the assessment of the evidence available and not the manner in which the Prosecutor conducted his investigations. ${ }^{65}$

Therefore, the Confirmation Decision displays continuity with the previous jurisprudence of the ICC, which has stressed that it is not the amount of Disclosed Evidence but its probative value [that] will prove essential and decisive for the Chamber when taking a decision [on the confirmation of charges], ${ }^{66}$ Indeed, Pre-Trial Chamber II had acknowledged that 'this approach enables the Chamber to make its determination pursuant to article 61(7) of the Statute even if the evidence as a whole relating to one charge lacks direct evidence, and is only supported by pieces of indirect evidence, provided that their probative value allows the Chamber to determine that the threshold established in that article is met. ${ }^{67}$ Even Pre-Trial Chamber I, in the Banda and Jerbo case, had held that the Prosecutor is not required to tender into the record of the case more evidence than is, in his view, necessary to convince the Chamber that the charges should be confirmed. ${ }^{68}$ When referring to the possibility for the Prosecutor to use, under Article 61(5), summary evidence, Pre-Trial Chamber I had unequivocally stated that the use of summary evidence is expressly allowed by the legal instruments of the Court and, accordingly, the Prosecutor should not be unduly prejudiced as a result of using such evidence.6 ${ }^{69}$ As clarified by the Appeals Chamber in Mbarushimana, the

64 See Sections 5 and 6 of this article.

65 Ruto, Kosgey and Sang Confirmation Decision, supra note 36, § 51.

66 Bemba Confirmation Decision, supra note 17, §60.

67 Ibid., §54.

68 Corrigendum of the 'Decision on the Confirmation of Charges, Banda and Jerbo (ICC-02/05-03/ 09-121-Corr-Red), Pre-Trial Chamber I, 8 March 2011, § 40.

69 Ibid., § 41. 
Prosecutor "need not submit more evidence than is necessary to meet the threshold of substantial grounds to believe. ${ }^{70}$

\section{The Obligation of a 'Largely Completed Investigation' at the Pre-Trial Stage: A Critical Analysis}

The Confirmation Decision appears consistent with the consolidated approach adopted by the ICC since Lubanga. This established interpretation of the evidentiary threshold, under Article 61(7), is characterized by a limited role for the Pre-Trial Chambers as quick and efficient gatekeepers. This implies that the Pre-Trial Chambers decide on the confirmation of charges as soon as possible after the suspect has made his or her first appearance before the bench. ${ }^{71}$ In other words, the case is to proceed to trial as soon as it has acquired a sufficiently defined structure from a factual and evidentiary point of view that meets the threshold of 'substantial grounds to believe'. It is then the responsibility of the Prosecutor to investigate further and prepare the case for trial on the basis of the charges confirmed by the Pre-Trial Chamber.

On the contrary, the Adjournment Decision provides that the Pre-Trial Chamber should confirm the charges and commit the suspect for trial, should there be sufficient evidence to do so, only when the Prosecutor's case appears prepared for trial since it does not require further investigations after the confirmation of charges. This approach implies that: (i) the evidence gathered through investigation, both incriminating and exculpatory, carried out by the Prosecutor is as complete as possible; (ii) the incriminating evidence collected is strongly oriented to establish the suspect's guilt; and (iii) the confirmation of charges hearing is more complex than under the 'traditional approach', given the amount of evidence that the parties will present, which may also lead the parties to call some witnesses to give live testimony.

In comparison with other cases before the Court, Pre-Trial Chamber I addressed the evidence not simply in terms of its probative value, but also evaluated the conduct of the investigation. It has been stressed elsewhere how the procedural obstacles related to the conduct of the investigation that surfaced in other cases, especially during the trial, may have had an indirect role in Pre-Trial Chamber I's decision to require the Prosecutor to present a very consolidated and well-structured case at the confirmation hearing. ${ }^{72}$ The expectation that the Prosecutor must present her strongest case, based on a largely completed investigation, appears to resemble more a desirable policy or practice that can, at best, be reasonably expected of an international prosecutor dealing with massive international crimes, rather than an obligation stemming from the ICC's applicable law. This conclusion finds support primarily in the wording of the Appeals Chamber, which has addressed the matter more than

70 Mbarushimana Appeal Judgment, supra note 12, $\$ 47$.

71 Art. 61(1) ICCSt.

72 Mariniello and Pons, supra author introductory note, at 228-320. 
once, yet always in non-binding terms. ${ }^{73}$ In Mbarushimana, it stated that, the investigation should be largely completed at the stage of the confirmation of charges hearing. Most of the evidence should therefore be available, and it is up to the Prosecutor to submit this evidence to the Pre-Trial Chamber. ${ }^{74}$

Previously, the Appeals Chamber had held that, "ideally, it would be desirable for the investigation to be complete by the time of the confirmation hearing, ${ }^{75}$ specifying, however, that, 'this is not a requirement of the Statute', and that the Prosecutor's investigation 'may be continued beyond the confirmation hearing. ${ }^{76}$ As correctly stressed by the Appeals Chamber, the duty to establish the truth, under Article 54, is not confined to the time before the confirmation hearing. Thus, for the purpose of establishing the truth, the Prosecutor must be allowed to continue her investigation even after the confirmation hearing. Imposing the legal requirement that investigation must be completed by the stage of the confirmation of charges, would entail the consequence of depriving the Court of significant and relevant evidence, namely, 'in situations where the ongoing nature of the conflict results in more compelling evidence becoming available for the first time after the confirmation hearing. ${ }^{77}$

In the same Judgment, the appeal Judges recognized that the threshold for the confirmation of charges ... is lower than convictions ... and may be satisfied before the end of the investigation. ${ }^{78}$ From this jurisprudence of the Appeals Chamber, it may be deduced that the Prosecutor does not have a legal obligation to put forth the strongest possible case based on a largely completed investigation.

Yet, despite the approach in Gbagbo lacking a legal foundation, the transformation of the role of the confirmation of charges procedure and, more generally, of the pretrial phase of a case might result in a number of advantages. Indeed, presenting the strongest possible case based on a largely completed investigation at the confirmation hearing could, in principle, contribute to the efficiency of the confirmation process, and result in a shorter preparation phase after the charges are confirmed, before the formal commencement of the trial. ${ }^{79}$ Most of the time saved by preparing the case for trial would derive from an easier redaction and disclosure process, 'as it may be expected that there are fewer differences between the Prosecutor's case as presented at the confirmation hearing and at trial. ${ }^{80}$ As a result, the Trial Chamber would not be inundated with a substantial new amount of evidence for which the parties may request redactions in respect of sensitive information before the start of

73 Dissenting Opinion of Judge Fernández, supra note 2, § 14 (emphasis added).

74 Mbarushimana Appeal Judgment, supra note 12, §44 (emphasis added).

75 Lubanga judgment, Pre-Trial Chamber I, supra note 50, § 54.

76 Ibid., $\$ 2$.

77 Ibid., $\$ 54$.

78 Ibid., $§ 56$.

79 See V. Nerlich, "The Confirmation of Charges Procedure at the International Criminal Court: Advance or Failure?' 10 JICJ (2012) 1339-1356, at 1355.

80 Ibid., at 1355. 
the trial, even if the Prosecutor is not prohibited, under the Statute, and as confirmed by the Appeals Chamber, from conducting additional investigations after the charges are confirmed and before the trial begins. Furthermore, it is argued that the more advanced the case at the time of the confirmation hearing, the more effective the filtering function of the Pre-Trial Chamber, as it will be better prepared to evaluate a substantial amount of evidence and decide which cases are worthy of trial. ${ }^{81}$

Notwithstanding the potential benefit of the Gbagbo Adjournment Decision approach, the move towards a strongest possible case based on a largely completed investigation' model has a number of undesirable consequences. First, it would probably result in a vast amount of evidence being submitted to the Pre-Trial Chamber. Hence, a more demanding process of evidentiary disclosure would ensue, in the course of which the Chamber would have to authorize redactions of such evidence proposed by the Prosecutor, pursuant to Rules 81(2) and (4) of the Rules, before disclosing said evidence to the Defence. ${ }^{82}$ This would, in turn, mean a longer process leading up to the confirmation of charges. Additionally, it would presumably entail the drafting of a far lengthier and detailed decision under Article 61(7), for the evidence to be evaluated and for the Chamber to decide whether there are substantial grounds to believe that the suspect has committed the crimes charged. In this regard, it should be emphasized that the suspect may be detained during the pretrial proceedings, if the grounds to deprive him or her of liberty still exist, as provided by Article 58(1)(b) of the Statute.

Secondly, the need to present the case in an advanced stage of preparation at the confirmation hearing would have consequences for the required quantity and quality of evidence, and might lead to a distortion of the confirmation of charges hearing, contrary to the purpose of Article 61 of the Statute. To understand these implications, it should be recalled that one of the main differences between the legal architecture of the confirmation of charges hearing and the trial proceedings at the ICC is that the Statute and the Rules of Procedure and Evidence (RPE) are more lenient with regard to the type and the quantity of evidence that can be presented by the Prosecutor at the confirmation hearing. ${ }^{83}$ Thus, the Prosecutor is free to present certain types of evidence and, at the same time, to withhold others without incurring any negative consequences for such decisions. More specifically, Article 61(5) of the Statute provides that the Prosecutor "may rely on documentary or summary evidence and need not call the witnesses expected to testify at the trial'. Furthermore, Article 61(5) and Rule 81(4) of the Rules have been interpreted as authorizing the non-disclosure of the identity of the witnesses whose statements the

81 Ibid., at 1356.

82 Ibid., at 1352.

83 Ibid., at 1343. For a discussion on the type of evidence that was used in the first confirmation hearing in the Lubanga case, see M. Miraglia, Admissibility of Evidence, Standards of Proof, and Nature of the Decision in the ICC Confirmation of Charges in Lubanga', 6 JICJ (2008) 489-503, at 496-497. 
Prosecutor intends to submit in summary form. ${ }^{84}$ It follows that the quality and quantity of the evidence that the Prosecutor may present 'to support each charge with sufficient evidence to establish substantial grounds to believe that the person committed the crimes charged', as mandated by Article 61(5), is significantly lower than the evidence that is needed to prove that the accused is guilty beyond a reasonable doubt.

This is not to say, however, that the Prosecutor will automatically obtain the confirmation of the charges by relying exclusively on documentary or summary evidence in support of her allegations. Nevertheless, this type of evidence may suffice in 'offer[ing] concrete and tangible proof demonstrating a clear line of reasoning underpinning [the] specific allegations, ${ }^{85}$ so as to "thoroughly ... satisfy [the Chamber] that the allegations are sufficiently strong to commit [the suspect] to trial. ${ }^{86}$ After all, the rationale of Article 61(5) of the Statute is connected to the purpose of the confirmation of charges hearing in light of the established evidentiary threshold of 'substantial grounds to believe', namely, to distinguish cases that are sufficiently strong to be sent to trial. The express authorization to rely on summary or documentary evidence finds its foundation in the legislative intent of the delegations to the Rome Conference, who considered Article 61(5) to be an appropriate solution to avoid the transformation of the confirmation hearing into a trial before the trial itself. ${ }^{87}$

Finally, if the items of evidence relied on at the confirmation hearing, were exactly or largely the same as those presented at trial 'the Pre-Trial Chamber's decision could influence the Trial Chamber thereby diminishing its "virginity". ${ }^{8}$ A lengthy analysis, by the Pre-Trial Chamber, of the probative value of the evidence presented by the Prosecutor, as a result of a largely completed investigation would, therefore, fall short of findings that would be for the Trial Chamber to make instead of the Pre-Trial Chamber. Thus, a decision

84 The Appeals Chamber has stated that '[t]he presentation by the Prosecutor of summaries of witness statements and other documents at the confirmation hearing is permissible even if the identities of the relevant witnesses have not been disclosed to the defence prior to the hearing, provided that such summaries are used in a manner that is not prejudicial to or inconsistent with the rights of the accused and a fair and impartial trial. See Judgment on the appeal of Mr. Thomas Lubanga Dyilo against the decision of Pre-Trial Chamber I entitled 'Second Decision on the Prosecution Requests and Amended Requests for Redactions under Rule 81', Lubanga (ICC-01/04-01/06-774), Appeals Chamber, 14 December 2006, § 2.

85 See Gbagbo Adjournment Decision, supra note 1, § 17, recalling the well-established jurisprudence on the interpretation of the substantial ground to believe threshold under Art. 61(7). See inter alia, Lubanga Confirmation Decision, supra note 16, § 39; Katanga and Ngudjolo Confirmation Decision, supra note 18, § 65; Garda Confirmation Decision, supra note 15, § 37; Decision on the Confirmation of Charges, Mbarushimana (ICC-01/04-01/10-465-Red), 16 December 2011, § 40; Bemba Confirmation Decision, supra note 17, § 29; Ruto, Kosgey and Sang Confirmation Decision, supra note $36, \S 40$.

86 Gbagbo Adjournment Decision, supra note 1, §17; Lubanga Confirmation Decision, supra note 16, $\S 39$.

87 See K. Shibahara and W.A. Schabas, 'Article 61: Confirmation of the Charges before the Trial', in O. Triffterer (ed.), Commentary on the Rome Statute of the International Criminal Court (Hart Publishing, 2008), at 1171.

88 Miraglia, supra note 83 , at 497. 
confirming the charges on the basis of nearly the same evidence presented at the trial stage would have little or no meaning, as it could appear as an anticipatory finding of the guilt of the suspect, even though the Pre-Trial Chamber has no power to enter a conviction.

The travaux préparatoires to the Statute also suggest that providing the PreTrial Chamber and, by implication, the Defence, with the entire case file of the Prosecutor was not considered to be an optimal solution, as it would have entailed unnecessary delays in the smooth conduct of the pretrial proceedings 'if the evidence collected in the case was excessive. ${ }^{89}$ Even if it would be beneficial that the Pre-Trial Chamber and Trial Chamber coordinated amongst themselves to envisage a uniform disclosure system, it is plausible that, in practice, the evidence would be collected and disclosed at the pretrial phase of the case only to be re-disclosed once again before the start of the trial, especially where the Trial Chamber has a different disclosure system. The litigation before the confirmation hearing and at the hearing itself would, therefore, be liable to increase as a result of the more extensive investigations conducted by the Prosecutor and the subsequent disclosure of such evidence. This could also multiply the number of interlocutory appeals lodged by the parties during the pretrial stage of the case.

In light of the foregoing considerations, it would be preferable that the Prosecutor submitted her case as soon as it is believed to be supported by evidence, including the type of evidence expressly mentioned in Article 61(5) of the Statute, sufficient to meet the substantial grounds to believe threshold. In this way, the right of the victims to receive justice and to participate in the proceedings would be safeguarded and implemented within a reasonable time. In addition, insofar as there is sufficient evidence to satisfy the evidentiary threshold for a case to proceed to the trial phase, no prejudice to the rights of the Defence can occur, provided that the suspect has the opportunity to exercise his or her rights during the course of the pretrial phase, as provided by Articles 61(6) and 67 of the Statute.

\section{Rethinking the Nature and Purpose of the Confirmation of Charges Procedure}

The Pre-Trial Chamber in the Adjournment Decision adopted a strict approach with respect to the application of the standard of proof, under Article 61(7) of the Statute, to the evidence presented by the Prosecutor at the confirmation hearing. This challenged the position in the previous jurisprudence regarding the purpose of the confirmation of charges stage. Indeed, the legal requirement providing that the Pre-Trial Chamber decides on the basis of a largely completed investigation and, thus, on a trial-ready evidence, reveals a view of the purpose of the confirmation of charges, which is seemingly oriented to a

89 See Report of the Preparatory Committee on the Establishment of an International Criminal Court, Vol. I, § 232. 
preliminary assessment of the guilt or innocence of the suspect. The standard of proof under Article 61(7), which imposes a largely completed investigation gathering the broadest range of incriminating and exculpatory evidence, appears to be interpreted by the majority of the Trial Chamber in light of the likelihood of a conviction at trial. This interpretation is confirmed by the words of Judge Van den Wyngaert, who was member of the majority delivering the Adjournment Decision, finding that 'charges should only be confirmed if the evidence has a realistic chance of supporting a conviction beyond reasonable doubt, ${ }^{, 0}$ and that, for the purposes of confirmation of charges, "there must be at least enough of an evidentiary basis to sustain a possible conviction on the assumption that these questions are resolved in favour of the Prosecutor at trial' (emphasis added). ${ }^{91}$

Thus, the confirmation of charges decision is transformed into a miniature judgment aiming to 'predict' whether the trial would be concluded with a conviction. Following the weaknesses and shortcomings in the Prosecutor's investigation related to different cases committed to trial, ${ }^{92}$ this approach strives to boost the role of the pretrial phase in ensuring judicial economy. The confirmation of charges becomes a highly selective filter, sending to trial only those cases, where the (trial-ready) evidence submitted by the Prosecutor shows realistically that the suspect would be liable beyond reasonable doubt at trial. Inconsistencies characterizing the evidence would (most likely) prevent judges from making a prognosis on the likelihood of the individual's guilt, and, as such, would lead judges to a decision declining the charges. As a consequence, the trial would be transformed into an exceptional stage, attained only by a minority of cases brought by the Prosecutor.

Despite the importance of judicial economy in international criminal proceedings, the interpretation of the confirmation of charges on the basis of the likely guilt would have destabilizing effects on the entire proceedings before the ICC, namely, on the relationship between the pretrial and trial phases. The more demanding and extensive the investigative burden is for the Prosecutor at the confirmation hearing (thus making it closer to a miniature trial), the more likely the actual trial is to become a mere rubber stamping of the findings made by the Pre-Trial Chamber, or at least a superfluous re-discussion thereof.

If charges have to be confirmed only when there is a strong evidentiary basis sustaining a possible conviction, the Pre-Trial Chamber's decision would become similar to a conviction judgment, even though the Pre-Trial Chamber has no power to enter a conviction. ${ }^{93}$ It could be argued that a highly selective decision, under Article 61(7), better safeguards the suspect against unfounded prosecutions. However, the main risk of the confirmation of charges based on the likelihood guilt is to deprive the pretrial phase in its entirety of its

90 Dissenting Opinion of Judge Van den Wyngaert, supra note 5, §4.

91 Ibid.

92 Mariniello and Pons, supra author introductory note, at 228-230.

93 With regard to the risk that the confirmation of charges may be (mis)interpreted as a presumption of guilt, see K. Ambos and D. Miller, 'Structure and Function of the Confirmation Procedure before the ICC', 7 International Criminal Law Review (2007) 335-360, at 348. 
protective role. Indeed, the confirmation of charges, oriented to determine the merits of the case as taken on the basis of an in-depth assessment of nearly the same evidence as presented at trial, risks committing cases for trials, commencing from an initial pre-judgment of the accused's guilt. In this way, the decision to confirm the charges would constitute an unacceptable stigma for the accused in the subsequent proceedings.

Additionally, the idea that the confirmation of charges has to provide a full reconstruction of the facts allegedly committed by the accused entails also the risk of transforming the pretrial phase into a duplication of the trial, with a serious impact on the expeditiousness of proceedings, as a fundamental element of the right to fair trial. This would also remove the need for a pretrial stage of proceedings as provided by the Statute.

Therefore, in light of these concerns, it seems more persuasive to emphasize how the role of judges in the pretrial division is not to provide a prognosis of the likelihood that the individual will be convicted or acquitted at trial, but it is, rather, confined to supervise the legitimacy of the prosecutor's request to commit an individual for trial. Instead of evaluating whether the evidence is sufficient to sustain a future conviction at trial, Pre-Trial Chambers are required to assess the utility of a full trial to resolve the contradictions of written evidence, by calling witnesses to give live testimony. As the evidentiary threshold for confirming the charges and committing a suspect to trial is lower than the standard of proof required to enter a conviction by a Trial Chamber, doubts concerning the facts as alleged by the Prosecutor against the defendant, in light of the evidence presented, will always remain at the end of the pretrial phase, even where the charges are confirmed.

It is true that, in contrast to ICTY and ICTR, the ICC Pre-Trial Chamber is vested with the authority to resolve ambiguities and inconsistencies in the credibility of evidence. However, as found by the Appeals Chamber, it is no less certain that the evaluation of such credibility is limited when witnesses do not testify in person at pretrial stage. ${ }^{94}$ In other words, the Pre-Trial Chamber's determinations of the credibility of witnesses will necessarily be presumptive. ${ }^{95}$ Thus, even if the available evidence does not appear sufficient to sustain a possible conviction at trial, a case could be worthy of trial if judges sitting in a Pre-Trial Chamber established that doubts and inconsistencies as to the credibility arising from the evidence may be more properly addressed and solved through the examination of witnesses at a trial. Therefore, the trial is the main forum in which the Trial Chamber, by way of fully testing the evidence in the courtroom, ascertains the facts and circumstances encompassed within the charges that were confirmed by the Pre-Trial Chamber, which may not have been completely clarified due to a potential combination of the incompleteness of the investigation, the lower evidentiary threshold applicable at the pretrial stage, and the different type of evidence allowed at this stage. In this context, even the request by the Pre-Trial Chamber to the 
Prosecutor to provide further evidence or conduct further investigation, under Article 61(7)(1)(c), has to be interpreted in light of such a limited purpose of the confirmation of charges. The rationale of requesting evidentiary integration is not to anticipate the outcome of the trial, but to provide judges with the possibility to assess the utility of the trial stage.

\section{Concluding Remarks}

The ICC Statute establishes four different, progressively higher evidentiary thresholds in Articles 53(1)(a), 58(1), 61(7) and 66(3). ${ }^{96}$ The lowest test is provided in the early stage of the proceedings, namely, in Article 53(1)(a) regarding the initiation of an investigation, where the Prosecutor has to assess whether or not there is a 'reasonable basis to believe that a crime within the jurisdiction of the Court has been or is being committed' (emphasis added). ${ }^{97}$ At the next, higher standard, the issuance of a warrant of arrest pursuant to Article 58(1) requires that there are 'reasonable grounds to believe that the person has committed a crime within the jurisdiction of the Court'. Situated immediately above, there is Article 61(7) providing a 'substantial grounds to believe' test for the purposes of the confirmation of charges. Finally, the highest threshold is enshrined in Article 66(3), according to which in order to convict the accused, the Court must be convinced of the guilt of the accused beyond reasonable doubts'. Judges sitting in the Pre-Trial Chamber have stated that 'the nature of these evidentiary thresholds depends on the different stages of the proceedings and is also consistent with the foreseeable impact of the relevant decisions on the fundamental human rights of the person charged. ${ }^{98}$

This article critically assessed the standard of proof for sending a case to trial under Article 61(7). It found that the requirement whereby the Prosecutor must present her strongest case, based on a largely completed investigation, for the purpose of the confirmation of charges lacks any legal basis. In the absence of an explicit legal foundation, it also appears impossible to determine whether the Prosecutor complied with her supposed obligation of a largely completed investigation.

In addition, the confirmation of charges hearing, which should have a primarily filtering function, would be transformed into an anticipation of the trial, and the decision, under Article 61(7), would become a 'miniature' judgment. Indeed, the standard of proof imposing a largely completed investigation reveals a model of confirmation of charges where the Pre-Trial Chambers decide whether to send a case to trial proceedings on the basis of the likelihood

96 See Ruto, Kosgey and Sang Confirmation Decision, supra note 36, $\S 40$. However, in the Bemba Confirmation Decision, supra note $17, \S 27$, Pre-Trial Chamber II found that there are only three evidentiary threshold, by omitting any references to Art. 53(1)(a).

97 The same evidentiary threshold is enshrined in Art. 15 with regard to the Pre-Trial Chamber's authorization for the Prosecutor to commence investigations proprio motu.

98 Bemba Confirmation Decision, supra note 17, § 27. 
of a conviction at trial. This would affect the sole competences of Trial Chambers, and would constitute a serious risk for the presumption of innocence. Indeed, the decision of confirmation of charges transformed into a preconviction judgment would weigh upon the accused as an enduring burden. The fact that the confirmation hearing would be a duplication of the trial would also remove the need for a pretrial stage of proceedings, as provided for in the Statute.

The recent confirmation of charges against Gbagbo presented a further evolution, as the Pre-Trial Chamber set aside the largely completed investigation requirement. ${ }^{99}$ The Pre-Trial Chamber stressed its authority to evaluate the evidence, but it emphasized its limited role in reaching conclusions on the credibility of witnesses. ${ }^{100}$ This means that, once the 'substantial grounds to believe' threshold is established, challenges to the credibility of evidence are to be more thoroughly addressed at trial. ${ }^{101}$ This interpretation of the standard of proof, under Article 61(7), appears more consistent with the limited scope and purpose of the confirmation of charges procedure. Therefore, compared to the Adjournment Decision, it better satisfies one of the essential elements characterizing the ICC's proceedings as shaped by the ICC Statute. Indeed, it contributes to maintain the purposes and legal tests at the confirmation hearing and at trial stage strictly apart.

To conclude, Pre-Trial Chambers have frequently emphasized that the confirmation of charges is neither a trial nor a mini-trial. Still, the judicial debate in Gbagbo reveals the necessity for the ICC to attempt to dissolve the uncertainty still surrounding the nature of the confirmation of charges procedure. According to this author, 13 years after the establishment of the Court, judges should clearly emphasize that the Pre-Trial Chamber's role is confined to the supervision of the legitimacy of the Prosecutor's request to commit an individual for trial, by assessing the utility of a full trial to resolve the contradictions of written evidence. The confirmation of charges aiming to evaluate the utility of the trial satisfies the main purpose of the pretrial stage to prevent unfounded and frivolous prosecution. Where judges, in Pre-Trial Chambers, believe that the Prosecutor has submitted unjustified charges, the individual has the possibility to avoid a lengthy trial, which would affect his/her legitimate interests and rights. Such a role for the Pre-Trial Chamber also reflects considerations of judicial economy, which justifies holding a trial only in cases of sufficiently well-founded allegations, bearing in mind the limited purpose of the confirmation of charges not precluding the Prosecutor from having an incomplete investigations at the pretrial stage. In other words, charges would be declined where the contradictions, ambiguities and inconsistencies in the evidence are so critical that they would not be untangled at the subsequent stage of a trial.

99 Gbagbo Confirmation Decision, supra note 3, $\$ \$ 21-23$.

100 Ibid., $\$ 21$.

101 Ibid. 